ҚАЗАҚСТАН РЕСПУБЛИКАСЫ

ҰЛТТЫҚ ҒЫЛЫМ АКАДЕМИЯСЫНЫН

АБАЙ АТЫНДАҒЫ ҚАЗАҚ ҰЛТТЫҚ

ПЕДАГОГИКАЛЫҚ УНИВЕРСИТЕТІНІҢ

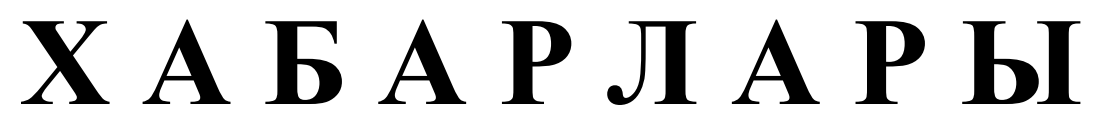

\section{ИЗВЕСТИЯ}

НАЦИОНАЛЬНОЙ АКАДЕМИИ НАУК РЕСПУБЛИКИ КАЗАХСТАН

КАЗАХСКИЙ НАЦИОНАЛЬНЫЙ

ПЕДАГОГИЧЕСКИЙ УНИВЕРСИТЕТ ИМ. АБАЯ

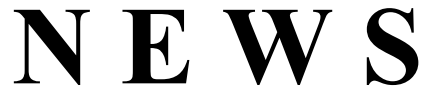

OF THE NATIONAL ACADEMY OF SCIENCES OF THE REPUBLIC OF KAZAKHSTAN

ABAY KAZAKH NATIONAL PEDAGOGICAL UNIVERSITY

ҚОҒАМДЫҚ ЖӘНЕ ГУМАНИТАРЛЫҚ ҒЫЛЫМДАР СЕРИЯСЫ

СЕРИЯ ОБЩЕСТВЕННЫХ И ГУМАНИТАРНЫХ НАУК

$\checkmark$

SERIES OF SOCIAL AND HUMAN SCIENCES

$$
5 \text { (321) }
$$

КЫРКУЙЕК - КАЗАН 2018 ж.

СЕНТЯБРЬ - ОКТЯБРЬ 2018 Г.

SEPTEMBER - OCTOBER 2018

1962 ЖЫЛДЫҢ ҚАНТАР АЙЫНАН ШЫҒА БАСТАҒАН

ИЗДАЕТСЯ С ЯНВАРЯ 1962 ГОДА

PUBLISHED SINCE JANUARY 1962

ЖЫЛЫНА 6 РЕТ ШЫҒАДЫ

ВЫХОДИТ 6 РАЗ В ГОД

PUBLISHED 6 TIMES A YEAR 
Ба с ре дактор

ҚР ҰҒА кұрметті мүшесі

Балықбаев Т.O.

Р е д а ц и я а лқ а сы:

экон. ғ. докторы, проф., ҚР ҰҒА академигі Баймұратов У.Б.; тарих ғ. докторы, проф., ҚР ҰҒА академигі Байпақов К.М.; филос. ғ.докторы, проф., ҚР ҰҒА академигі Есім Г.Е.; фил. ғ. докторы,, проф., ҚР ҰҒА академигі Қирабаев С.С.; эк. ғ. докторы, проф., ҚР ҰҒА академигі Кошанов А.К.; эк.ғ. докторы, проф., ҚР ҰҒА академигі Нәрібаев К.Н. (бас редактордың орынбасары); филос. ғ.докторы, проф., ҚР ҰҒА академигі Нысанбаев А.Н.; заң ғ. докторы, проф., ҚР ҰҒА академигі Сәбікенов С.Н.; заң ғ. докторы, проф., ҚР ҰҒА академигі Сүлейменов М.К.; эк. ғ. докторы, проф., ҚР ҰҒА академигі Сатыбалдин С.С.; тарих ғ. докторы, проф., ҚР ҰҒА академик Әбжанов Х.М.; тарих ғ. докторы, проф., ҚР ҰҒА корр. мүшесі Әбусеитова М.Х.; тарих ғ. докторы, проф., ҚР ҰҒА академик Байтанаев Б.А.; филол. ғ. докторы, проф., ҚР ҰҒА корр. мүшесі Жақып Б.А.; фил. ғ. докторы, проф., академик НАН РК Қалижанов У.К.; филол. ғ. докторы, проф., ҚР ҰҒА академик Қамзабекұлы Д.; тарих ғ. докторы, проф., ҚР ҰҒА академик Қожамжарова Д.П.; тарих ғ. докторы, проф., ҚР ҰҒА академик Койгелдиев М.К.; фил. ғ. докторы, проф., ҚР ҰҒА корр. мүшесі Кұрманбайұлы Ш.; тарих ғ. докторы, проф., ҚР ҰҒА корр. мүшесі Таймағанбетов Ж.К.; социол. ғ. докторы, проф., ҚР ҰҒА корр. мүшесі Шәукенова 3.К.; фил. ғ. докторы, проф., КР ҰҒА корр. мүшесі Дербісәлі А.; саяси. ғ. докторы, проф., Бижанов А.К., тарих ғ. докторы, проф., Кабульдинов 3.Е.; фил. ғ. докторы, проф., ҚР ҰҒА корр мүшесі Қажыбек Е.3.

\section{Р едакция ке н е с i:}

Молдова Республикасының ҰҒА академигі Белостечник Г. (Молдова); Әзірбайжан ҰҒА академигі Велиханлы Н. (Азербайджан); Тәжікстан ҰҒА академигі Назаров Т.Н. (Тәжікстан); Молдова Республикасының ҰҒА академигі Рошка А. (Молдова); Молдова Республикасының ҰҒА академигі Руснак Г. (Молдова); Әзірбайжан ҰҒА корр. мүшесі Мурадов Ш. (Әзірбайжан); Әзірбайжан ҰҒА корр. мүшесі Сафарова 3. (Әзірбайжан); э. ғ. д., проф. Василенко В.Н. (Украина); заң ғ. докт., проф. Устименко В.А. (Украина)

«Қазақстан Республикасы Ұлттық ғылым академиясының Хабарлары. Қоғамдық және гуманитарлық ғылымдар сериясы». ISSN 2224-5294

Меншіктенуші: «Қазақстан Республикасының Ұлттық ғылым академиясы» РҚБ (Алматы қ.)

Қазақстан республикасының Мәдениет пен ақпарат министрлігінің Ақпарат және мұрағат комитетінде 30.04.2010 ж. берілген № 10894-Ж мерзімдік басылым тіркеуіне қойылу туралы куәлік

Мерзімділігі: жылына 6 рет.

Тиражы: 500 дана.

Редакцияның мекенжайы: 050010, Алматы қ., Шевченко көш., 28, 219 бөл., 220, тел.: 272-13-19, 272-13-18, http://nauka-nanrk.kz. social-human.kz

(C) Қазақстан Республикасының Ұлттық ғылым академиясы, 2018

Типографияның мекенжайы: «Аруна» ЖК, Алматы қ., Муратбаева көш., 75. 
Главный редакто $p$

Почетный член НАН РК

T.O. Балыкбаев

Р е дак ци онн а я коллег и я:

докт. экон. Н., проф., академик НАН РК У.Б. Баймуратов; докт. ист. н., проф., академик НАН РК К.М. Байпаков; докт. филос. Н., проф., академик НАН РК Г.Е. Есим; докт. фил. Н., проф., академик НАН РК С.С. Кирабаев; докт. экон. Н., проф., академик НАН РК А.К. Кошанов; докт. экон. Н., проф., академик НАН РК К.Н. Нарибаев (заместитель главного редактора); докт. филос. н., проф., академик НАН РК А.Н. Нысанбаев; докт. юр. Н., проф., академик НАН РК С.Н. Сабикенов; докт. юр. н., проф., академик НАН РК М.К. Сулейменов; докт. экон. Н., проф., академик НАН РК С.С. Сатубалдин; докт. ист. н., проф., академик НАН РК Х.М. Абжанов; докт. ист. н., проф., чл.-корр. НАН РК М.Х. Абусеитова; докт. ист. н., проф., академик НАН РК Б.А. Байтанаев; докт. фил. н., проф., чл.-корр. НАН РК Б.А. Жакып; докт. фиолол. н., проф., академик НАН РК У.К. Калижанов; докт. фил. н., проф., академик НАН РК Д. Камзабекулы; докт. ист. н., проф., академик НАН РК Д.П. Кожамжарова; докт. ист. н., проф., академик НАН РК М.К. Койгельдиев; докт. филол. н., проф., чл.-корр. НАН РК Ш. Курманбайулы; докт. ист. н., проф., чл.корр. НАН РК Ж.К. Таймаганбетов; докт. социол. н., проф., чл.-корр. НАН РК З.К. Шаукенова; д. филол. н., проф., чл.-корр. НАН РК А. Дербисали; доктор политических наук, проф., Бижанов А.К.; доктор ист. наук, проф., Кабульдинов 3.Е.; доктор филол. н., проф., член-корр. НАН РК Қажыбек Е.3.

Р е дак ци онны й с ов е т

академик НАН Республики Молдова Г. Белостечник (Молдова); академик НАН Азербайджанской Республики Н. Велиханлы (Азербайджан); академик НАН Республики Таджикистан Т.Н. Назаров (Таджикистан); академик НАН Республики Молдова А. Рошка (Молдова); академик НАН Республики Молдова Г. Руснак (Молдова); чл.-корр. НАН Азербайджанской Республики Ш. Мурадов (Азербайджан), член-корр. НАН Азербайджанской Республики 3.Сафарова (Азербайджан); д. э. н., проф. В.Н. Василенко (Украина); д.ю.н., проф. В.А. Устименко (Украина)

Известия Национальной академии наук Республики Казахстан. Серия общественных и гуманитарных наук. ISSN 2224-5294

Собственник: РОО «Национальная академия наук Республики Казахстан» (г. Алматы)

Свидетельство о постановке на учет периодического печатного издания в Комитете информации и архивов

Министерства культуры и информации Республики Казахстан № 10894-Ж, выданное 30.04.2010 г.

Периодичность 6 раз в год

Тираж: 500 экземпляров

Адрес редакции: 050010, г. Алматы, ул. Шевченко, 28, ком. 219, 220, тел. 272-13-19, 272-13-18, www:nauka-nanrk.kz / social-human.kz

(C) Национальная академия наук Республики Казахстан, 2018 г.

Адрес типографии: ИП «Аруна», г. Алматы, ул. Муратбаева, 75

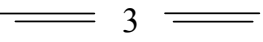


Chief Editor

\section{Honorary member of NAS RK \\ Balykbayev T.O}

Editorial board:

Doctor of economics, prof, academician of NAS RK Baimuratov U.B.; doctor of history, prof, academician of NAS RK Baipakov K.M.; doctor of philosophy, prof, academician of NAS RK Esim G.E.; doctor of philology, prof, academician of NAS RK Kirabayev S.S.; doctor of economics, prof, academician of NAS RK Koshanov A.K.; doctor of economics, prof, academician of NAS RK Naribayev K.N. (deputy editor-in-chief); doctor of philosophy, prof, academician of NAS RK Nyssanbayev A.N.; doctor of law, prof, academician of NAS RK Sabikenov S.N.; doctor of law, prof, academician of NAS RK Suleymenov M.K.; doctor of economy, prof, academician of NAS RK Satybaldin S.S.; doctor of history, prof, academician of NAS RK Abzhanov H.M; doctor of history, prof, corresponding member of NAS RK Abuseitova M.H.; doctor of history, prof, academician of NAS RK Baitanaev B.A.; doctor of philology, prof, corresponding member of NAS RK Zhakyp B.A.; doctor of philology, prof, academician of NAS RK Kalizhanov U.K.; doctor of philology, prof, academician of NAS RK Hamzabekuly D.; doctor of history, prof, academician of NAS RK Kozhamzharova D.P.; doctor of history, prof, academician of NAS RK Koigeldiev M.K.; doctor of philology, prof, corresponding member of NAS RK Kurmanbaiuly Sh.; doctor of history, prof, academician of NAS RK Taimaganbetov J.K.; doctor of sociology, prof, corresponding member of NAS RK Shaukenova Z.K.; doctor of philology, prof, corresponding member of NAS RK Derbisali A.; doctor of political science, prof Bizhanov A.K; doctor of History, prof Kabuldinov Z.E.; doctor of philology, prof, corresponding member of NAS RK Kazhybek E.Z.

\section{Editorial staff:}

Academician NAS Republic of Moldova Belostechnik.G (Moldova); Academician NAS Republic of Azerbaijan Velikhanli N. (Azerbaijan); Academician NAS Republic of Tajikistan Nazarov T.N. (Tajikistan); Academician NAS Republic of Moldova Roshka A. (Moldova) Academician NAS Republic of Moldova Rusnak G. (Moldova); Corresponding member of the NAS Republic of Azerbaijan Muradov Sh. (Azerbaijan); Corresponding member of the NAS Republic of Azerbaijan Safarova Z. (Azerbaijan); Associate professor of Economics Vasilenko V.N. (Ukraine), Associate professor of Law Ustimenko V.A. (Ukraine)

News of the National Academy of Sciences of the Republic of Kazakhstan. Series of Social and Humanities. ISSN 2224-5294

Owner: RPA "National Academy of Sciences of the Republic of Kazakhstan" (Almaty)

The certificate of registration of a periodic printed publication in the Committee of information and archives of the Ministry of culture and information of the Republic of Kazakhstan N 10894-Ж, issued 30.04.2010

Periodicity: 6 times a year

Circulation: 500 copies

Editorial address: 28, Shevchenko str., of. 219, 220, Almaty, 050010, tel. 272-13-19, 272-13-18, www:nauka-nanrk.kz / social-human.kz

(C) National Academy of Sciences of the Republic of Kazakhstan, 2018

Address of printing house: ST "Aruna", 75, Muratbayev str, Almaty 
N E W S

OF THE NATIONAL ACADEMY OF SCIENCES OF THE REPUBLIC OF KAZAKHSTAN

SERIES OF SOCIAL AND HUMAN SCIENCES

ISSN 2224-5294

https://doi.org/10.32014/2018.2224-5294.16

Volume 5, Number 321 (2018), 89 - 94

UDC 338.27(574)

\author{
Tlessova Elvira, Khoich Aizhan, Kurash Nazerke \\ L.N. Gumilyov Eurasian National University \\ t.ilvira@mail.ru, ayjika@mail.ru, naz-9393@list.ru
}

\title{
SCIENTIFIC INNOVATION POTENTIAL OF THE REPUBLIC OF KAZKAHSTAN AND ITS PERSPECTIVES
}

\begin{abstract}
In the modern world economy countries that can use innovations can win major international competition. However, each country has such an opportunity for development, which is determined by the scientific innovation potential of each country. In this regard, the most important issue is the study of the process of formation and development of the national innovation system (NIS) in Kazakhstan and the improvement of the organizational economic mechanisms of its functioning.

The main subsystems of Kazakhstan`s NIS according to the program creation and development of NIS of Republic of Kazakhstan, are scientific potential, innovative entrepreneurship, innovative and financial infrastructure.

Science is an important part of the national heritage, which is the main resource of economic and social changes in the country. In many cases, the scientific potential determines the country's place in the world community, the prospects for competition in foreign markets and the ability to solve its internal problems. The article describes the scientific innovation potential of Kazakhstan and shows the percentage of indicators of our country's scientific potential for many years. At the same time, the dynamics of the development of highly qualified specialists, the number of researchers who develop the country's scientific potential, are presented through tables and clearly defined requirements for their qualification.

The author has analyzed the statistical data of the main indicators of scientific and innovative development of the Republic of Kazakhstan. The author also analyzes the country's scientific potential, draws several conclusions and suggests effective ways of developing scientific innovation potential.
\end{abstract}

Key words: innovation, innovation potential, science, innovative development.

\section{INTRODUCTION}

In the modern world, in the context of accelerating scientific and technological progress innovations are becoming crucial for the sustainable growth of the national economy which is increasing its competitiveness. Countries that pursue an active innovation policy and create a favorable economic climate for innovation demonstrate high rates of economic development, high competitiveness of manufactured goods and services in international markets.

Innovation is a process that ensures the growth of competitiveness and turns scientific results into a new technological process or product. Only those countries that can use innovations in the modern world economy can win major international competition. However, each country has such an opportunity for development, which is determined by the scientific innovation potential of each country. In this regard, the most important issue is the study of the process of formation and development of the national innovation system (NIS) in Kazakhstan and the improvement of the organizational economic mechanisms of its functioning.

President of the Republic of Kazakhstan N.Nazarbayev in his message to the people of Kazakhstan "Strategy of Kazakhstan-2050": the new political course of the developed state ", noted the need to support the promotion of innovations in the national economy:" ... the introduction of innovations is important, but this is not the main goal. When our new technologies are in demand, they will be able to benefit from the country only when it is necessary on the market. Otherwise, innovation is a waste of money "[1]. 
The study of NIS determines its complex structure, consisting of interconnected subsystems, which include a number of elements in each of them. All levels of the NIS are interrelated and mutually complementary. Despite the diversity of elements of national innovation systems, all elements of this system that have a certain integrity serve a common goal. In this regard, particular attention is paid to the construction of systems, their main components, their interconnection and interaction.

\section{MAIN PART}

For the successful development of NIS is the effective functioning of all subsystems and their elements. The main subsystems of Kazakhstan's NIS according to the program creation and development of the National Innovation System of the Republic of Kazakhstan, are scientific potential, innovative entrepreneurship, innovative and financial infrastructure.

Let's look at the key indicators that characterize the effective functioning of the subsystems of Kazakhstan`s NIS. After gaining independence, the scientific and technical potential of the transition period was significantly lost. Scientific and project development was not required, as a result of low funding, many sectors of the research institute and design organizations were eliminated. Human resources have also decreased significantly [2].

In the Republic of Kazakhstan, scientific research and development in 2017 involved 386 organizations (in 2016 - 383 organizations). According to the Statistics Committee of the Ministry of National Economy of the Republic of Kazakhstan, the number of research organizations has declined, but in 2017 this indicator increased by 13,2\% compared to 2013 [3]. The growth rates of organizations are shown in Table 1.

Table 1 - Number of organizations engaged in R\&D in 2013-2017 by sector of activity, units.

\begin{tabular}{|l|l|l|l|l|l|l|}
\hline Types of organizations & 2013 & 2014 & 2015 & 2016 & 2017 & $\begin{array}{l}\text { Growth rate, (2017- } \\
2013) / 2013 * 100 \%, \%\end{array}$ \\
\hline All organizations,units & 341 & 392 & 390 & 383 & 386 & 13,2 \\
\hline Public sector & 78 & 100 & 94 & 100 & 101 & 29,5 \\
\hline $\begin{array}{l}\text { Higher vocational educational } \\
\text { sector: }\end{array}$ & 112 & 107 & 103 & 103 & 99 & $-11,6$ \\
\hline $\begin{array}{l}\text { Business sector } \\
\text { Non-profit sector }\end{array}$ & 110 & 147 & 154 & 149 & 146 & 32,7 \\
\hline Note - Committee on Statistics of MNE RK: http://stat.gov.kz [3]. & 49 & 31 & 40 & $-2,44$ \\
\hline
\end{tabular}

The public sector, including institutions funded from the state budget, in 2017 was represented by 101 organizations.

The number of organizations in the business sector, including organizations whose main activity is related to the production of products or services for sale, decreased by 3 units in comparison with 2016 .

The higher education sector (99 organizations) includes universities, institutes, academies and other institutions of post-secondary education, regardless of the source of their funding and legal status; research institutes, experimental laboratories and clinics, which are managed by institutions of higher education.

The smallest number of organizations is represented in the non-profit sector of science, which includes legal entities funded by private non-profit organizations - 40 .

Research structures ensure the development of new breakthrough technologies that will subsequently be introduced in industrial enterprises, the rapidity and efficiency of the commercialization of new ideas and developments largely depends on their location. The absence of such organizations in industrial enterprises makes them unable to conduct research and development, which excludes them from the process of innovative development. Many industrial enterprises of Kazakhstan are still focused only on technology transfer, because do not have the financial means to conduct the entire cycle of R \& D and the introduction of innovations in production.

Table 2 shows structure of the distribution of organizations engaged in R \& D. It should be noted that most of this rise is accounted for business sector in the overall structure of organizations. 
Table 2 - Structure of the distribution of organizations engaged in R \& D, \%

\begin{tabular}{|l|l|l|l|l|l|}
\hline Sectors & 2013 & 2014 & 2015 & 2016 & 2017 \\
\hline All organizations & 100 & 100 & 100 & 100 & 100 \\
\hline Public sector & 22,9 & 25,8 & 24,1 & 26,1 & 26,2 \\
\hline Higher vocational educational sector: & 32,8 & 26,8 & 26,4 & 26,9 & 25,7 \\
\hline Business sector & 32,3 & 38 & 39,5 & 38,9 & 37,82 \\
\hline Non-profit sector & 12 & 9,4 & 10,0 & 8,1 & 10,36 \\
\hline Note- Committee on Statistics of MNE RK: http://stat.gov.kz [3]. \\
\hline
\end{tabular}

According to the statistical data of Table 2, we will determine the linear coefficient of absolute structural shifts of the number of R \& D organizations by sectors of the economy. In the conditions of measuring absolute structural shifts, the classical formula of the average linear deviation is transformed into the following:

$$
L_{b}^{A b}=\frac{\sum_{i=1}^{n}\left|d_{j}-d_{0}\right|}{n}
$$

$\mathrm{d}$ - specific weight of the characteristics; $\mathrm{n}$ - number of gradations in the structures; $\mathrm{j}$ - current period; 0 base period.

$$
L_{17 / 13}^{A b}=\frac{|26,2-22,9|+|25,7-32,8|+|37,82-32,3|+|10,36-12|}{4}=4,39
$$

This coefficient characterizes the average value of deviations from the specific weights, which means how many percentage points on average the relative weights of the parts in the compared populations deviate from each other.

The more value of the linear coefficient of absolute structural shifts, the greater the relative weights of the individual parts for the two compared periods on average, the greater the absolute structural shifts.

The value of the coefficient for the period 2013-2017 is 4.39\%, which indicates structural shift in the number of organizations performing R \& D in Kazakhstan by sectors of the economy during this period.

Along with scientific and research organizations, the country's scientific potential includes highly qualified specialists capable of developing ideas that are subsequently embodied in innovative products and technologies. Innovative economics makes high demands on the number and level of qualifications of scientific workers.

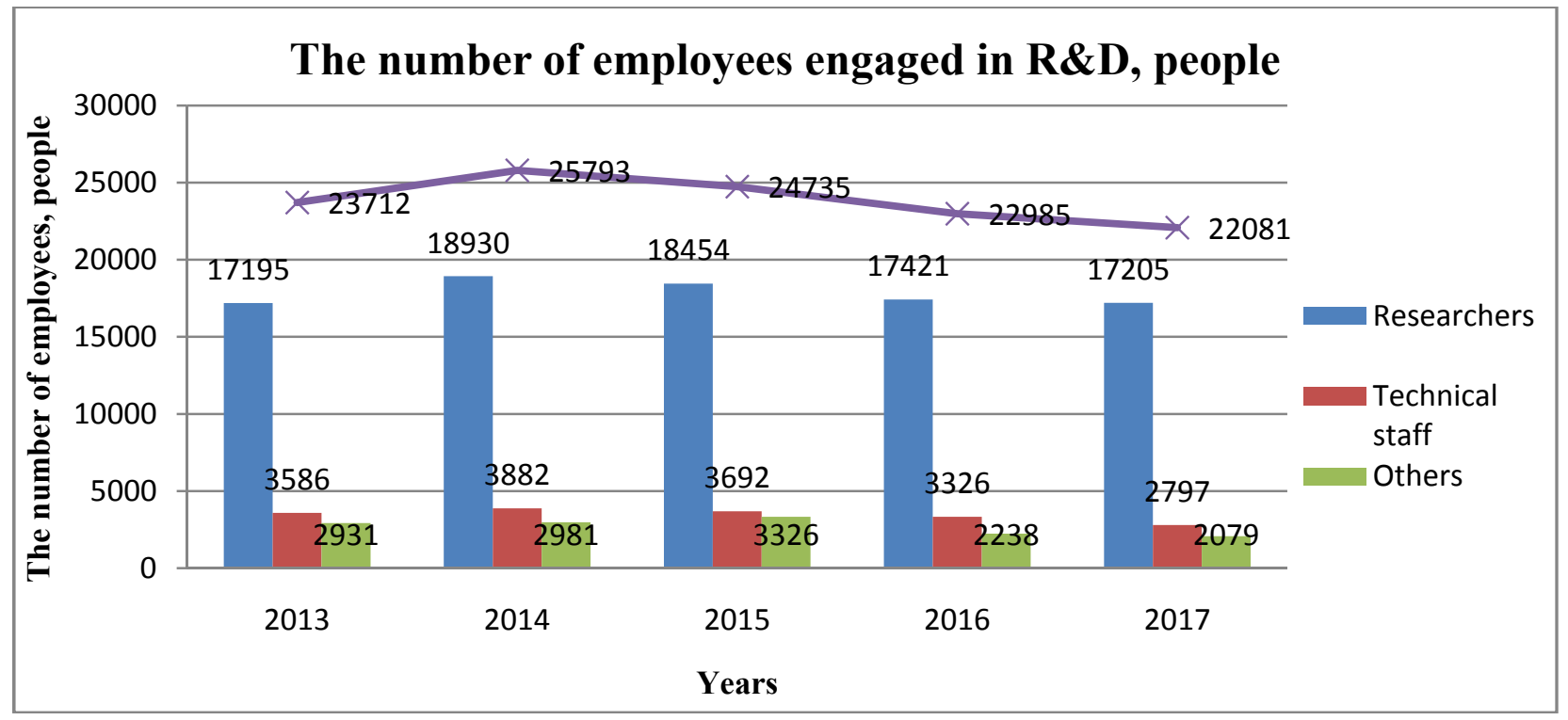

Figure 1 - The number of employees engaged in R\&D, people

Note - Made by authors on the basis of a source [3],[4],[5]. 
In scientific research and development 22,081 people were involved in 2017, (in 2016 - 22,985 people), including 17,205 research specialists. Compared with 2014, in which the largest number of employees was registered during the five-year period, in 2017 the number of employees engaged in R\&D decreased by 3.7 thousand people (Figure 1).

In 2016, out of 17,400 researchers, the largest the number (5.2 thousand) was involved in the field of natural sciences. At the same time, the staff of the highest qualification comprised: doctors of sciences 574 people, candidates -1.3 thousand, PhDs -200 and doctors on the profile -199 . The number of masters was 1.2 thousand people [6].

The largest number of research specialists in 2017 was involved in the field of engineering sciences- 5 thousand. The number of cadres of the highest scientific qualifications in this field of science was only in the second position and amounted to 2,557 people: 979 candidates, 383 doctors of science, 114 doctors of philosophy $\mathrm{PhD}$ and 77 doctors on the profile; 1000 masters. In general, the share of researchers in the engineering sciences accounted for about $29.3 \%$ of the total number. Then follow the natural sciences, where the share of research specialists accounted for $29 \%$. The number of candidates of sciences was 1221 people, doctors - 577, doctors on the profile - 117, doctors of philosophy PhD - 224 and masters - 1236 people. The least represented by the highly qualified personnel were medical sciences. They accounted for only $6.1 \%$ of the number of research specialists. In this field of science the smallest number of highly qualified personnel was noted: candidates -327 people, doctors - 182, doctors on the profile -47 , doctors of philosophy $\mathrm{PhD}-31$ people, masters - 202 people.

Table 3 - Dynamics of the number of researchers with scientific degrees

\begin{tabular}{|l|l|l|l|l|l|l|}
\hline Indicators & 2013 & 2014 & 2015 & 2016 & 2017 & $\begin{array}{l}\text { Growth rate, } \\
2017 / 2013, \%\end{array}$ \\
\hline $\begin{array}{l}\text { Number of staff engaged in research and } \\
\text { development (at the end of the year), people }\end{array}$ & 23712 & 25793 & 24735 & 22985 & 22081 & 93,1 \\
\hline including researchers, people: & 17195 & 18930 & 18454 & 17421 & 17205 & 100,0 \\
\hline Doctor of Science & 1688 & 2006 & 1821 & 1828 & 1818 & 107,7 \\
\hline Doctor by profile & 605 & 596 & 549 & 493 & 354 & 58,5 \\
\hline PhD philosophy & 218 & 330 & 431 & 456 & 589 & 270,2 \\
\hline Candidates of Science & 4915 & 5254 & 5119 & 4754 & 4541 & 92,4 \\
\hline Note- Made by authors on the basis of a source [3],[4],[5]. & & & & \\
\hline
\end{tabular}

The analysis of the formation of a contingent of human potential with the highest scientific qualification shows that there is a shift towards the number of doctors of philosophy $(\mathrm{PhD})$ and doctors in the profile, whose preparation is carried out in Kazakhstan. The number of specialists in these qualifications has increased in all areas of science.

A special event of this year for the science of our country was the Address of the President of the country N.A. Nazarbayev to the people of Kazakhstan on January 10, 2018, "New Development Opportunities in the Conditions of the Fourth Industrial Revolution," which sets the task of increasing the efficiency and effectiveness of science, synchronizing it with the innovative development of the republic's economy. For this it is necessary: Development of high school science with a priority on research in metallurgy, oil and gas chemistry, agro-industrial complex, bio- and IT-technologies; Implementation of joint projects by universities with leading foreign universities and research centers, large enterprises and TNCs; Co-financing from the private sector of all applied research and development; System policy to support young scientists with the allocation of quotas within the framework of scientific grants; Implementation of the phased transition to English of applied scientific research [7].

\section{CONCLUSION}

Concluding the analysis of the scientific potential of Kazakhstan, the main directions for the further development of Kazakhstan's science are the following:

1. Increase in the demand for the results of scientific developments in the real sector of the economy. An important direction in the development of the scientific sphere remains integration into the world scientific space. At present, international cooperation in the field of science and technology is developing on the basis of bilateral agreements with 33 countries of the world. 
2. Development of effective mechanisms to increase the competitiveness of the human resources potential of science. To achieve a breakthrough, it is necessary to create favorable stimulating conditions for young, promising scientists. In order to strengthen the scientific and human potential of the country in 2017, the state educational order for the preparation of $\mathrm{PhD}$ doctors was first increased. So, in 2017, 1437 grants were awarded (in 2016 - 780), for the preparation of undergraduates was awarded 10735 grants (in $2016,8160)$.

3. To pay attention to the main priorities of the development of science of Kazakhstan. The priorities includes:

- Rational use of natural resources, including water resources, geology, processing, new materials and technologies, safe products and structures;

- Power engineering and machine building;

- Information, telecommunication and space technologies, scientific research in the field of natural sciences;

- Sustainable development of the agro-industrial complex and safety of agricultural products;

- National security and defense.

4. Another urgent task is digitalization, which is applied not only in the science of Kazakhstan, but also penetrated into all spheres of society: the economy, government bodies, law, business structures, etc.

\section{REFERENCES}

[1] «Kazahstanskij put' - 2050: Edinaja cel', edinye interesy, edinoe budushhee» Poslanie Prezidenta Respubliki Kazahstan N.Nazarbaeva narodu Kazahstana. Astana,17 janvarja 2014 g. www.akorda.kz.

[2] Bopieva Zh.K. Jekonomicheskie osnovy sistemnoj transformacii jekonomiki Kazahstana (opyt reformirovanija i problem modernizacii). Karaganda: TOO Arko, 2001. $283 \mathrm{~s}$.

[3] Committee on Statistics of Ministry of National Economics of the RK (2017). The official statistical information: http://stat.gov.kz.

[4] Predvaritel'nye dannye za 2017 god. Statisticheskij ezhegodnik.- Astana, 2018. 214 s. Rezhim dostupa: http://stat.gov.kz.

[5] Nacional'nyj doklad po nauke. Astana; Almaty, 2018. 120 s. http://nauka-nanrk.kz/ru/nac-doklad.html.

[6] Konstruktorskie bjuro. AO «Nacional'noe agentstvo po tehnologicheskomu razvitiju»// Nacional'nyj doklad po nauke. - Astana; Almaty, 2017. - 152 s. http://analytics.natd.gov.kz/uploads/sections/74/nacionalnyy-doklad-po-nauke-2017-komitetnauki_74_20180913.pdf.

[7] State of the Nation Address by the President of the Republic of Kazakhstan Nursultan Nazarbayev «New opportunities under the fourth industrial revolution». Astana, 10 January 2018.www.akorda.kz.

УДК 338.27(574)

\section{Тлесова Эльвира, Хойч Айжан, Кураш Назерке}

Евразийский национальный университет им.Л.Н. Гумилева

\section{НАУЧНО-ИННОВАЦИОННЫЙ ПОТЕНЦИАЛ РЕСПУБЛИКИ КАЗКАСТАН И ЕГО ПЕРСПЕКТИВЫ}

Аннотация. В современной глобальной экономике те страны, которые могут быстро и правильно использовать инновации, могут достичь международной конкурентоспособности. Однако каждая страна имеет аналогичный потенциал развития, который определяется научным и инновационным потенциалом каждой страны. В этой связи одним из актуальных вопросов является изучение процесса формирования и развития национальной инновационной системы в Казахстане и предложения по совершенствованию организационных экономических механизмов его функционирования.

Основными подсистемами национальной инновационной системы Казахстана, принятыми в рамках программы создания и развития Национальной инновационной системы, являются научный потенциал. Поэтому сегодня в числе актуальных проблем внесены предложения по формированию и развитию национальной инновационной системы в Казахстане и улучшению экономических механизмов ее функционирования.

Наука является важной частью национального наследия, которое является основным ресурсом экономических и социальных изменений в стране. Во многих случаях научный потенциал определяет место 
страны в мировом сообществе, перспективы конкуренции на внешних рынках и способность решать свои внутренние проблемы. В статье описывается научно-инновационный потенциал Республики Казахстан и показывает процент показателей (рост или сокращение) научного потенциала нашей страны на протяжении многих лет. В то же время динамика развития высококвалифицированных специалистов, число исследователей, которые развивают научный потенциал страны, представлены через таблицы и четко определены требования к их квалификации.

Автор проанализировал статистические данные основных показателей научно-инновационного развития Республики Казахстан. Автор также анализирует научный потенциал страны и делает несколько выводов и предлагает эффективные способы развития инновационного научного потенциала.

Ключевые слова: инновация, инновационный потенциал, наука, инновационное развитие.

УДК $338.27(574)$

\section{Тлесова Эльвира, Хойч Айжан, Кураш Назерке}

\section{Л.Н. Гумилев атындағы Еуразия ұлттық университеті}

\section{ҚАЗАҚСТАН РЕСПУБЛИКАСЫНЫН ҒЫЛЫМИ ИННОВАЦИЯЛЫҚ ПОТЕНЦИЯСЫ ЖӘНЕ ОНЫН ПЕРСПЕКТИВАЛАРЫ}

Аннотация. Қазіргі әлемдік экономикада инновацияны тез әрі дұрыс пайдалана алатын елдер ғана халықаралық бәсекеде жеңіске қол жеткізе алады. Алайда әр елдің мұндай даму мүмкіндігі әртүрлі, олар әр елдің ғылыми инновациялық әлеуетімен анықталады. Осыған байланысты, Қазақстандағы ұлттық инновациялық жүйенің қалыптасу және даму процесін зерттеу, оның қызмет етуінің ұйымдастырушылық экономикалық механизмдерін жетілдіру бойынша ұсыныстарды енгізу өзекті мәселелердің бірі болып отыр.

Ұлттық инновациялық жүйені құру және дамыту бағдарламасы аясында қабылданған Қазақстанның ұлттық инновациялық жүйесінің негізгі қосалқы жүйелеріне ғылыми әлеует те жатады. Сондықтан Қазақстандағы ұлттық инновациялық жүйенің қалыптасуы мен даму процесін зерттеу, оның қызмет етуінің экономикалық механизмдерін жетілдіру жайлы ұсыныстар енгізу бүгінгі таңдағы өзекті мәселелердің бірінен саналады.

Ғылым саласы еліміздің экономикалық және әлеуметтік өзгерістерінің іргелі ресурсы саналатын ұлттық мұраның маңызды бөлігі болып табылады. Көптеген жағдайларда ғылыми әлеует елдің әлемдік қоғамдастықтағы орнын, сыртқы нарықтағы бәсекелестік күрестегі перспективаларын және оның ішкі мәселелерін шешу мүмкіндігін анықтайды. Мақалада Қазақстан Республикасының ғылыми инновациялық әлеуетіне сипаттама жасалып, еліміздің әр жылдардағы ғылыми әлеуетінің көрсеткіштерінің пайыздық мөлшері (өсу немесе қысқару деңгейі) көрсетілген. Сонымен қатар еліміздің ғылыми әлеуетін дамытатын жоғары білікті мамандардың, ғылыми қызметкерлердің санының даму динамикасы кестелер арқылы беріліп, олардың біліктілік дәрежесіне қойылатын талаптар да нақты айтылады.

Автор мақалада Қазақстан Республикасының ғылыми инновациялық дамуының негізгі көрсеткіштерінің статистикалық деректерін қолданып оған талдау жасаған. Сондай-ақ автор еліміздің ғылыми әлеуетін талдай отырып, бірнеше қорытынды жасайды және бүгінгі күні инновациялық ғылыми әлеуетті дамытудың тиімді жолдарын ұсынады.

Түйін сөздер: инновация, инновациялық әлеует, ғылым, инновациялық даму.

Information about author:

Tlessova Elvira - L.N. Gumilyov Eurasian National University, t.ilvira@mail.ru, https://orcid.org/0000-0001-7057-0461;

Khoich Aizhan - L.N. Gumilyov Eurasian National University, ayjika@mail.ru, https://orcid.org/0000-0002-0128-3052;

Kurash Nazerke - L.N. Gumilyov Eurasian National University, naz-9393@list.ru, https://orcid.org/0000-0002-9187-4306 


\section{МАЗМҰНЫ}

Алтыбаева С.М., Савындыков Е.С. Көркем мәтін құрылымындағы мифопоэтикалық модельдеу және мәдени код...... 5 Сембиева Л.М., Мажитов Д.М., Карпиикая М.Е., Хамитова Д.М. Экономиканы жаңғырту жағдайындағы ЕАЭО елдерінің монетарлық жүесінін өзгеруі .....

Құлсариева А.Т., Султанова М.Э., Шайгозова Ж.Н. Фольклор және сәйкестілік: Қазақстанның қазіргі заманғы

мәдениетіндегі тарих, жады және аңыз шығармашылығы ........................................................................................... 19

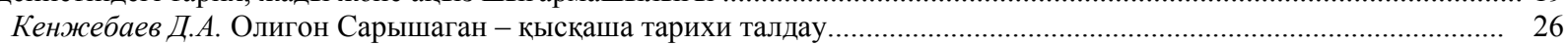

АбдулинаГ.А., БазарбаевА.Г. Ұйымдардағы адам ресурстарын басқарудың заманауи тұжырымдамалары................ 33

Авыбаев А.Н., Адибаева А.К. Геноцид туралы БҰҰ Конвенциясының қатысушы мемлекеттердің қылмыстық

заңнамаларындағы имплементациялық тетіктері: жалпы салыстырмалы талдау............................................................ 39

Ахметжанов Б., Тәжібекова К.Б., Шаметова А.А. Қазақстан көлік өнеркәсіптің дамуын талдау............................. 44

Аюпова 3.К., Құсайынов Д.Ө. Тәуелсіздік жағдайындағы қазақстан республикасының конституциялық-құқықтық

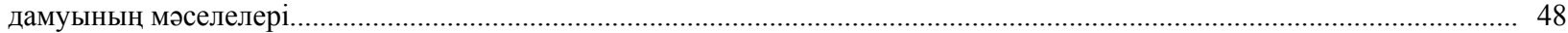

Нурпеисова А.А., Рей И.Ю., Бижанов Д.Т., Тлеужанова Д.А. Инновациялық өндірісді жасаудың процесін

бақылауының негізгі элементтері

Гиздатов Г.Г. Қазақстандық дискурсының құрылымы психолингвистиякалық зерттеу .

Ищанова Р.К. Мемлекеттік шығындарды басқару - мемлекеттің қаржылық тұрақтылығын қамтамасыз ету.............. 64

Мадышева А.М. Бикенова А.С., Елеусиз Л.Т. Білім саласындағы туристік қызметтер............................................. 68

Ескалиева А. Ж., Баймуханова М.Т., Ахмурзина Д.О. Әлеуметтік сала адам капиталының сапасын қолдаудың

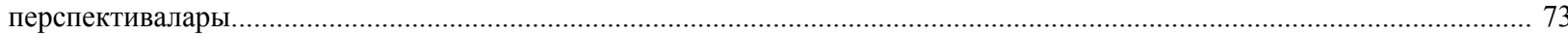

Мархаева Б.А., Козбахова Д.Л. Жауапкершілік орталық және трансферттік баға белгілеу............................................ 79

Сабирова Р.К., Утепкалиева К.М., Кабаков С.Б. Қазақстандағы ауыл шаруашылығы экономикасының

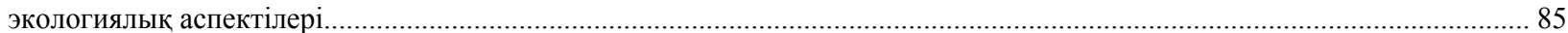

Тлесова Э., Хойч А., Кураш Н. Қазақстан республикасының ғылыми инновациялық потенциясы және оның

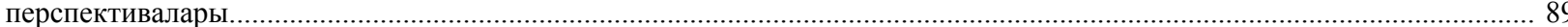

Хамитхан Н. Қазақстандағы банктік қызметтердің сапасын жақсарту жағдайында банкаралык басекелестік............ 95

Шалдарбеков Қ.Б., Муханова Г.С., Нурмухамбетова 3.С. Аймақтарды дамыту бағдарламаларын жүзеге асырудағы жобалық басқаруды қолданудың шетелдік тәжірибесі

КаратаеваА.М., Бердиярова Ж.С. Мемлекеттік қызметшінің әдептік мәдениеті және құқықтық мәдениеті

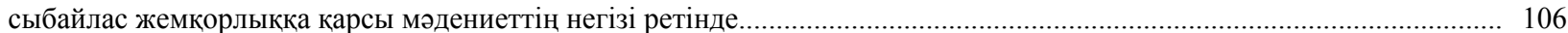

Алдабергенова А.А. Абсурд әдебиетін аударудың лингвомәдени аспектілері ................................................... 113

Стукач В. Ф., Байдалинова А. С., Сандыбаева Б. А. Қазақстанның қаржылық қауіпсіздігі......................................... 119

Баймаханова Д.М., Оспанова Д.А. Конституциялық-құқықтық сана - конституционализмнің маңызды

компоненті ретінде және оның адам құқықтары мәселелерін шешудегі рөлі................................................................. 126

Имангожина 3.А. Сланцевая революция: глобальный тренд на мировом энергетическом рынке............................. 137

Ракаева А.Н., Жуматаева Б.А., Успамбаева М.К., Доскалиева Б.Б. Экологиялық есеп қазақстандағы кәсіпорын экономикасының даму кезеңі ретінде

Нуржанова Г.И. Экономиканың аграрлық секторындағы еңбек әлеуетіне демографиялық фактордың әсері............ 147

Оспанова Д.А., Баймаханова Д.М. Қазақстан Республикасының кибер кеңістігін дамыту жағдайында мемлекеттік қызметтерді цифрландыруда әкімшілік-құқықтық қамтамасыз ету ................................................................................... 152

Pblсnекова М.О., Тлесова Э.Б., Хаитбаева Ф.К. Қазақстандағы тұрғын үй-коммуналдық шаруашылық қызметін

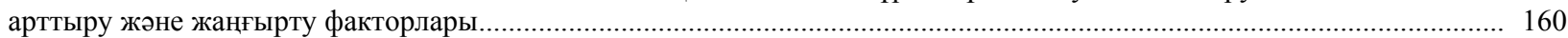

Султанова Г. Т. Аграрлық сектордың экспорттық әлеуетін дамытуға бағытталған үрдістер мен басымдықтар........ 166 


\section{СОДЕРЖАНИЕ}

Алтыбаева С.М., Сагындыков Е.С. Культурный код и мифопоэтическое моделирование в структуре художественного текста.

Сембиева Л.М., Мажитов Д.М., Карпиикая М.Е., Хамитова Д.М. Трансформация монетарной системы стран

ЕАЭС в условиях модернизации экономики.............................................................................................................

Кулсариева А.T., Султанова М.Э., Шайгозова Ж.Н. Фольклор и идентичность: история, память и мифотворчество

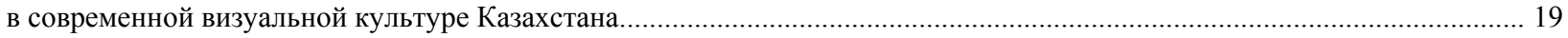

Кенжебаев Д.А. Полигон Сарышаган - краткий исторический анализ................................................................ 26

Абдулина Г.А., БазарбаевА.Г. Современные концепции управления человеческми ресурсами в организациях........... 33

Агыбаев А.Н., Адибаева А.К. Имплементационные механизмы Конвенции ООН о геноциде в уголовных

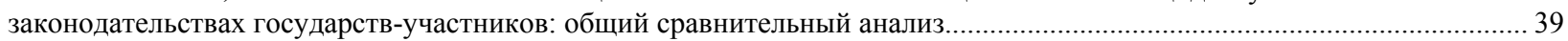

Ахметжанов Б., Тажибекова К.Б., Шаметова А.А. Анализ развития угольной промышленности Казахстана........... 44

Аюпова 3.К., Кусаинов Д.У.Проблемы конституционно-правового развития республики Казахстан в условиях

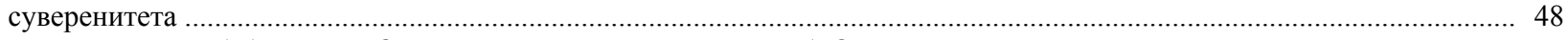

Нурпеисова А.А., Рей И.Ю., Бижанов Д.Т., Тлеужанова Д.А. Основные элементы управления процессом создания

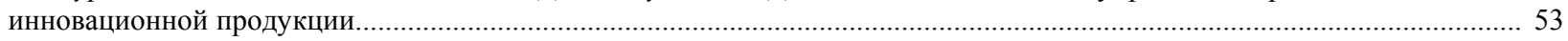

Гиздатов Г.Г. Психолингвистическое исследование концептов казахстанского дискурса...................................... 57

Ищанова Р.К. Управление государственными расходами - как обеспечение финансовой устойчивости государства. 64

Мадымева А.М. Бикенова А.С., Елеусиз Л.Т. Туристские услуги в сфере образования........................................... 68

Ескалиева А. Ж., Баймуханова М.Т., Ахмурзина Д.О. Перспективы усиления качества человеческого капитала

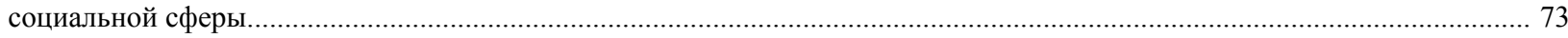

Мархаева Б.А., Козбахова Д.Л. Центр ответственности и трансфертное ценообразование..................................... 79

Сабирова Р.К., Утепкалиева К.М., Кабаков С.Б. Экологические аспекты экономики сельского хозяйства

в Казахстане........................................... 85

Тлесова Э., Хойч А., Кураш Н. Научно-инновационный потенциал республики Казкастан и его перспективы............ 89

Хамитхан Н. Межбанковская конкуренция в условиях повышения качества банковских услуг в Казахстане.............. 95

Шалдарбеков К.Б., Муханова Г.С., Нурмухамбетова 3.С. Зарубежный опыт применения проектного управления

при реализации программ развития регионов

Каратаева А.М., Бердиярова Ж.С. Этическая культура и правовая культура государственных служащих

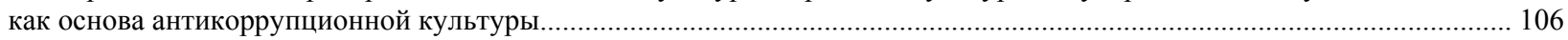

Алдабергенова А.А. Лингвокультурологические аспекты перевода литературы абсурда.......................................... 113

Стукач В. Ф., Байдалинова А. С., Сандыбаева Б. А. Казахстанская финансовая безопасность.................................... 119

Баймаханова Д.М., Оспанова Д.А. Конституционно-правовое сознание как важный компонент конституционализма

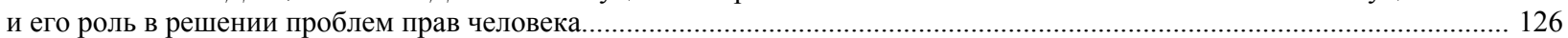

Имангожина 3.A. Сланцевая революция: глобальный тренд на мировом энергетическом рынке............................. 137

Ракаева А.Н., Жуматаева Б.А., Успамбаева М.К., Доскалиева Б.Б. Экологический учет как ступень развития

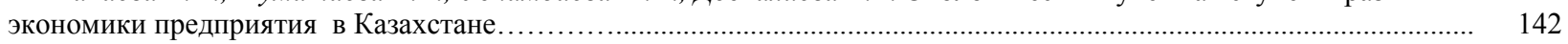

Нуржанова Г.И. Влияние демографического фактора на трудовой потенциал аграрного сектора экономики............ 147

Оспанова Д.А., Баймаханова Д.М. Административно-правовое обеспечение цифровизации государственных услуг

в условиях развития кибер пронстранства республики Казахстан..

Pыспекова М.О., Тлесова Э.Б., Хаитбаева Ф.К. Факторы инновационной модернизации и совершенствования

деятельности жилищно-коммунального хозяйства в Казахстане.

160

Султанова Г. Т. Тенденции и приоритеты развития экспортного потенциала аграрного сектора................................ 166 


\section{CONTENTS}

Altybayeva S.M., Sagyndykov E.S. Cultural code and myth poetic modeling in the structure of the artistic text..................... 5 Sembiyeva L.M., Mazhitov D.M., Karpitskaya M.E., Khamitova D.M. Transformation of the monetary system of the eurasian economic UNION countries in the conditions of modernization of the economy......

Kulsarieva A.T., Sultanova M.E., Shaigozova Zh.N. Folklore and identity: history, memory and myth-making in the modern

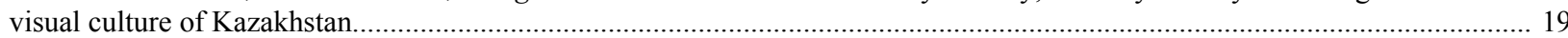

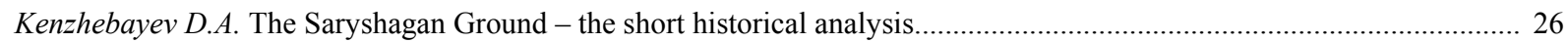

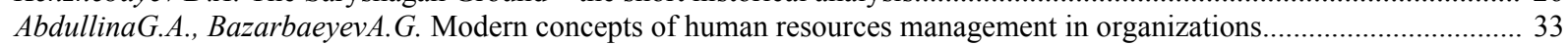

Agybayev A.N., Adibayeva A.K. Implementing mechanisms of the UN Convention on genocide in the criminal legislation

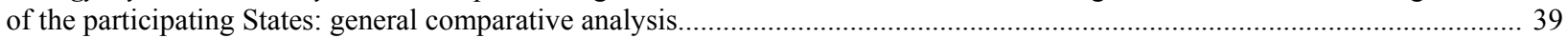

Akhmetzhanov B., Tazhibekova K.B, Shametova A.A. Analysis of development of the coal industry of Kazakhstan.............. 44 Ayupova Z.K., Kussainov D.U. Problems of constitutional and legal development of the republic of kazakhstan in the conditions of sovereignty......

Nurpeisova A.A., Rey I.Yu., Bizhanov D.T., Tleuzhanova D.A. Main elements of managing the process of creating innovation production.

Gizdatov G.G. Psycholinguistic study of the concepts of Kazakhstar

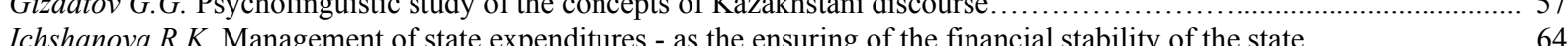

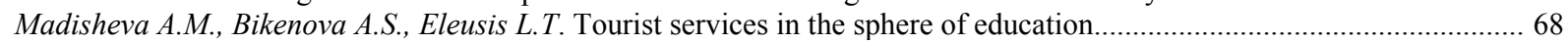

Eskalieva A. Zh., Baymukhanova M.T., Ahmurzina D.O. Perspectives of strengthening the quality of the human capital

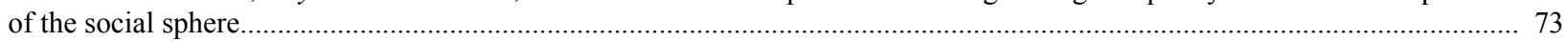

Markhayeva B.A., Kozbakhova D.L. A responsibility center and transfer pricing ................................................. 79

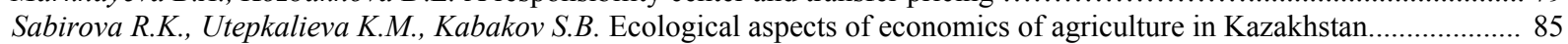

Tlessova E., Khoich A., Kurash N. Scientific innovation potential of the republic of Kazkahstan and its perspectives........ 89

Hamitkhan $N$. Interbank competition in conditions of improving the quality of banking services in Kazakhstan.................. 95

Shaldarbekov K., Mukhanova G., Nurmukhambetova Z. International practices in project management in implementing

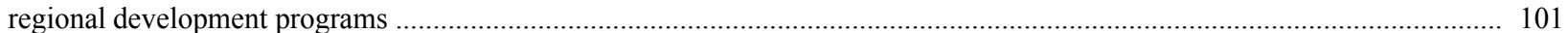

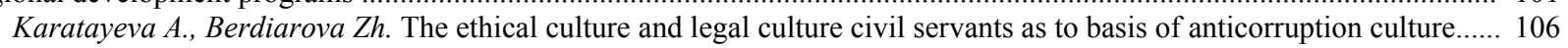

Aldabergenova A.A. Linguocultural aspects of translation of absurd literature.............................................................. 113

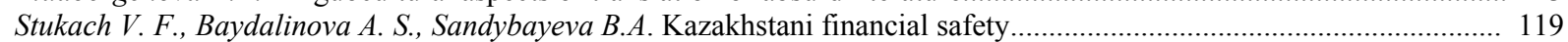

Baimakhanova D.M., Ospanova D.A. Constitutional and legal consciousness as an important component of constitutionalism

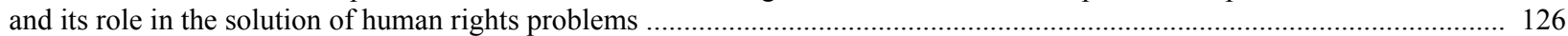

Imangozhina Z.A. Shale gas revolution: global trend in the world energy market..................................................... 137

Rakaeva A.N., Zhumataeva B.A., Uspanbayeva M.K., B.B.Doskalieva. Level of ecological report development in the economic of Kazakhstan's companies.

Nurzhanova G.I. Impact of demographic factors on labor potential of economy's agricultural sector

Ospanova D.A., Baimakhanova D.M. Administrative and legal support of digitalization of public services in the context of the development of cyber space in the republic of Kazakhstan....

Ryspekova M.O., Tlessova E.B., Khaitbayeva F. Factors of innovative modernization and improvement of activity

of housing and communal services in Kazakhstan.

Sultanova G. T. Trends and priorities for the development of export potential of the agrarian sector. 


\title{
PUBLICATION ETHICS AND PUBLICATION MALPRACTICE IN THE JOURNALS OF THE NATIONAL ACADEMY OF SCIENCES OF THE REPUBLIC OF KAZAKHSTAN
}

For information on Ethics in publishing and Ethical guidelines for journal publication see http://www.elsevier.com/publishingethics and http://www.elsevier.com/journal-authors/ethics.

Submission of an article to the National Academy of Sciences of the Republic of Kazakhstan implies that the work described has not been published previously (except in the form of an abstract or as part of a published lecture or academic thesis or as an electronic preprint, see http://www.elsevier.com/postingpolicy), that it is not under consideration for publication elsewhere, that its publication is approved by all authors and tacitly or explicitly by the responsible authorities where the work was carried out, and that, if accepted, it will not be published elsewhere in the same form, in English or in any other language, including electronically without the written consent of the copyrightholder. In particular, translations into English of papers already published in another language are not accepted.

No other forms of scientific misconduct are allowed, such as plagiarism, falsification, fraudulent data, incorrect interpretation of other works, incorrect citations, etc. The National Academy of Sciences of the Republic of Kazakhstan follows the Code of Conduct of the Committee on Publication Ethics (COPE), and follows the COPE Flowcharts for Resolving Cases of Suspected Misconduct (http://publicationethics.org/files/u2/New Code.pdf). To verify originality, your article may be checked by the originality detection service Cross Check http://www.elsevier.com/editors/plagdetect.

The authors are obliged to participate in peer review process and be ready to provide corrections, clarifications, retractions and apologies when needed. All authors of a paper should have significantly contributed to the research.

The reviewers should provide objective judgments and should point out relevant published works which are not yet cited. Reviewed articles should be treated confidentially. The reviewers will be chosen in such a way that there is no conflict of interests with respect to the research, the authors and/or the research funders.

The editors have complete responsibility and authority to reject or accept a paper, and they will only accept a paper when reasonably certain. They will preserve anonymity of reviewers and promote publication of corrections, clarifications, retractions and apologies when needed. The acceptance of a paper automatically implies the copyright transfer to the National Academy of sciences of the Republic of Kazakhstan.

The Editorial Board of the National Academy of sciences of the Republic of Kazakhstan will monitor and safeguard publishing ethics.

Правила оформления статьи для публикации в журнале смотреть на сайте:

$$
\begin{gathered}
\text { www:nauka-nanrk.kz } \\
\text { social-human.kz }
\end{gathered}
$$

\author{
Редакторы М.С. Ахметова, Т.А. Апендиев, Д.С. Аленов \\ Верстка на компьютере А.М. Кульгинбаевой \\ Подписано в печать 10.10.2018 \\ Формат 60x881/8. Бумага офсетная. Печать - ризограф. \\ 11,6 п.л. Тираж 500. Заказ 5.
}

